\title{
Terrace Garden using Solar Energy Planting Systems in IoT
}

\section{Govindharaj, Vimala D, Shanmugapriya K}

\begin{abstract}
Internet of things (IOT) is the network of different "things" or "objects" which is usually web-enabled devices that collect, send data through sensors, electronics, and software. In today's world automatic system is more preferred than manual and also it is difficult to water and maintain the terrace garden in person who is working or an aged. To overcome this issue, if LPC2418 microcontroller is used which automates the watering and monitoring the plants in terrace garden, it will yield good performance in terms of QOS like response time, availability and efficiency.
\end{abstract}

Keywords: Web-enabled devices, automatic system, LPC2418 microcontroller, automatic watering, monitoring, response time, availability, efficiency.

\section{INTRODUCTION}

Internet of things is the network connection of unique identifier which has embedded[1],[3],[5]
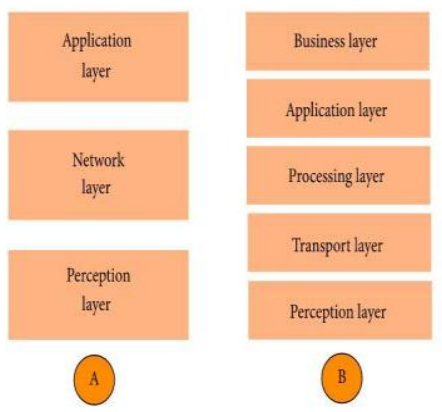

Figure 1: Different Architecture model

Technologies that enable to sense, gather and communicate data through the environment. The vast network of devices which gets connected to the internet, devices with the sensors, devices including smart phone and tablet collect and exchange data. These objects are sensed and controlled by the existing network. These devices collect and send data [18-24] with the help of various technologies and flow the data [between other devices.

Internet of things is not result of single technology but

Revised Manuscript Received on August 22, 2019.

I.Govindharaj Department of Computer science and Engineering, Bharath Institute of Higher Education and Research, Chennai, Tamilnadu, India.Email: gvraj87@gmail.com

Vimala D, Department of Computer science and Engineering, Bharath Institute of Higher Education and Research, Chennai, Tamilnadu, India.Email: vimalamuthu3@gmail.com

Shanmugapriya K, Department of Computer science and Engineering, Bharath Institute of Higher Education and Research, Chennai, Tamilnadu, India.Email: shanmugapriyabiher@gmail.com combination of various technologies which provide capabilities to build or develop virtual and real world. The various capabilities include. sensing, addressability, user friendly interfaces [6-17], identification Sensors provide inputs about the current state and actuators are used to effect the environmental change. Internet of things not only uses sensing capabilities but also uses actuation capabilities for example applications that deal with heat, electricity and energy management.

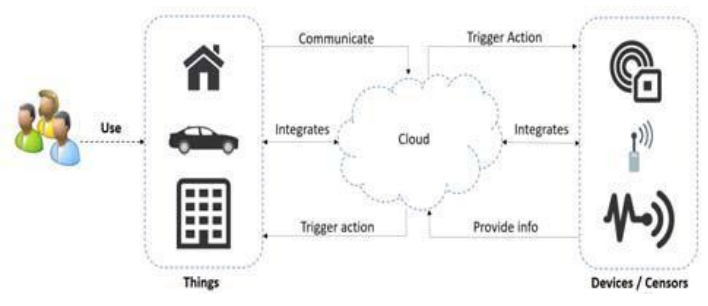

Figure 2: General Architecture of IOT

Different IOT architecture includes three and five layer architecture and cloud and fog based architecture. In the former architecture, the transport layer transfers the data between layers, the processing layer act as middleware, the business layer manages the whole IoT system. Applications include biosensor taken by people, transportation vehicle, equipment in public places and much more. Internet of Things integrates human society and physical world.

Internet of things

1.Identify things and track them

2.Collect and process the data [2],[4],[6]

3.Enhance the collected data

4.Make the collected data interact with other devices. Massive potential of IOT include improved performance, reduced costs, create innovative services, new revenue stream.

Internet of things (IOT) is a developing technology leading to a revolution from transport to general purpose household applications. Internet of Things actually works with integration of internet and devices using IP address as a unique identifier. Usually the IPv6 is used to accommodate the large scale application as it requires larger address space.

After all the unique features and various advantages of IoT, it does face various challenges at present such as scalability, power supply, fault tolerance, interoperability and 
software complexity, privacy, absence of governance ,data storage and analytics, lack of solid business models. Iot will have revolutionary effect in near future in various dimensions like traffic issue, daily life and domestics, retailing, logistics, health monitoring, resource [37-41] and power control.

\section{RELATED WORKS}

The project titled "GARDUINO" is deliberate to construct an automated gardening monitoring mechanism which switches the water pump in between $\mathrm{ON}$ and OFF states on detecting the moisture level of the soil. The advantage of using this system is to lessen human interference. This project uses an arduino microcontroller which is programmed to amass the data from various sensors used. This system will reduce the human efforts in gardening and also make the gardening automated and tech friendly.

Rachna Gera [1], Ankit Vashista et. al. , have proposed a system which will monitor the household gardens which can further be expanded to farmhouses. They have used a GSM to communicate with users to have complete visibility. In this system they have used soil moisture sensor controlled by adruino board to keep track of when to water the plants through an ON and OFF switch. But the author did not address the issues like availability of power supply, including more sensors for betterment of farming like finding nutrients in the soil[25],[27],[29].

The proposed system can be improved when the issues are addressed. The proposed system does automatic monitoring of the household garden by supplying adequate water at regular intervals based on the moisture content, since GSM is used it gives a message to the user when to ON and OFF the water supply.

\section{RESULTS}

To address the issue of availability of power supply and proper intimation about the growth of plants,

1. If solar cells are used instead of current supply, efficiency of the system will be improved.

2. If this system is testes using LPC 2418 ARM 7 processor performance can be improved.

3. Water flow indicator can also be fixed to make intimation about the availability of water.

4. To quantify this algorithm, better to conduct bench mark results of various existing algorithms[14],[16],[18].

\section{CONCLUSION}

Internet of things (IOT) is becoming a revolutionary technology in terms of all fields like transportation, healthcare, agriculture. IOT provides communication of devices so that user interference is highly reduced and improved. Through this major domain we have proposed a

system for automation of household gardening in small scale which can be further expanded to fields in large scale. Our system overcomes the issue of absence of power supply, accurate monitoring of plants' growth by height sensor and surveillance camera. This system is connected to mobile phone of the user so that intimation can be given easily.

\section{REFERENCES}

1. Gowri Sankaran, B., Karthik, B. \& Vijayaragavan, S.P. 2019, "Weigh ward change region plummeting change for square based image huffman coding", International Journal of Innovative Technology and Exploring Engineering, vol. 8, no. 10, pp. 4313-4316.

2. Gowri Sankaran, B., Karthik, B. \& Vijayaragavan, S.P. 2019, "Image compression utilizing wavelet transform", International Journal of Innovative Technology and Exploring Engineering, vol. 8, no. 10, pp. 4305-4308.

3. Kandavel, N. \& Kumaravel, A. 2019, "Offloading computation for efficient energy in mobile cloud computing", International Journal of Innovative Technology and Exploring Engineering, vol. 8, no. 10, pp. 4317-4320.

4. Vinoth, V.V. \& Kanniga, E. 2019, "Reversible data hiding in encrypting images-an system", International Journal of Engineering and Advanced Technology, vol. 8, no. 6, pp. 3051-3053.

5. Selvapriya, B. \& Raghu, B. 2019, "Pseudocoloring of medical images: A research", International Journal of Engineering and Advanced Technology, vol. 8, no. 6, pp. 3712-3716.

6. Senthil Kumar, K. \& Muthukumaravel, A. 2019, "Bi-objective constraint and hybrid optimizer for the test case prioritization", International Journal of Engineering and Advanced Technology, vol. 8, no. 6, pp. 3436-3448.

7. Kavitha, G., Priya, N., Anuradha, C. \& Pothumani, S. 2019, "Read-write, peer-to-peer algorithms for the location-identity split", International Journal of Innovative Technology and Exploring Engineering, vol. 8, no. 9 Special Issue 3, pp. 445-447.

8. Kaliyamurthie, K.P., Michael, G., Anuratha, C. \& Sundaraj, B. 2019, "Certain improvements in alzheimer disease classification using novel fuzzy c means clustering for image segmentation", International Journal of Innovative Technology and Exploring Engineering, vol. 8, no. 9 Special Issue 3, pp. 599-604.

9. Kaliyamurthie, K.P., Sundarraj, B., Geo, A.V.A. \& Michael, G. 2019, "RIB: Analysis of I/O automata", International Journal of Innovative Technology and Exploring Engineering, vol. 8, no. 9 Special Issue 3, pp. 1019-1022.

10. Velvizhi, R., Rajabhushanam, C. \& Vidhya, S.R.S. 2019, "Opinion mining for travel route recommendation using Social Media Networks (Twitter)", International Journal of Innovative Technology and Exploring Engineering, vol. 8, no. 9 Special Issue 3, pp. 508-512.

11. Kavitha, R., Sangeetha, S. \& Varghese, A.G. 2019, "Human activity patterns in big data for healthcare applications", International Journal of Innovative Technology and Exploring Engineering, vol. 8, no. 9 Special Issue 3, pp. 1101-1103.

12. Pothumani, S., Anandam, A.K., Sharma, N. \& Franklin, S. 2019, "Extended VEOT framework - Implemented in a smart boutique", International Journal of Innovative Technology and Exploring Engineering, vol. 8, no. 9 Special Issue 3, pp. 762-767.

13. Kaliyamurthie, K.P., Michael, G., Krishnan, R.M.V. \& Sundarraj, B 2019, "Pseudorandom techniques for the internet", International Journa of Innovative Technology and Exploring Engineering, vol. 8, no. 9 Special Issue 3, pp. 915-918.

14. Aravindasamy, R., Jeffrin Rajan, M., Rama, A. \& Kavitha, P. 2019, "Deep learning provisions in the matlab: Focus on CNN facility", International Journal of Innovative Technology and Exploring Engineering, vol. 8, no. 9 Special Issue 3, pp. 990-994.

15. Theivasigamani, S., Linda, M. \& Amudha, S. 2019, "Object sensing and its identification \& motion sensing", International Journal of Innovative Technology and Exploring Engineering, vol. 8, no. 9 Special Issue 3, pp. 545-549.

16. Mary Linda, I., Vimala, D. \& Shanmuga Priya, K. 2019, "A methodology for the emulation of IPv4", International Journal of Innovative Technology and Exploring Engineering, vol. 8, no. 9 Special Issue 3, pp. 848-852. 
17. Velvizhi, R., Priya, D.J., Vimala, D. \& Linda, I.M. 2019, "Increased routing algorithm for mobile adhoc networks", International Journal of Innovative Technology and Exploring Engineering, vol. 8, no. 9 Special Issue 3, pp. 1606-1608

18. Sangeetha, S., Anuradha, C. \& Priya, N. 2019, "DNS in real world", International Journal of Innovative Technology and Exploring Engineering, vol. 8, no. 9 Special Issue 3, pp. 937-940.

19. Geetha, C., Vimala, D. \& Priya, K.S. 2019, "Constructing multi-processors and spreadsheets with SKIVE", International Journal of Innovative Technology and Exploring Engineering, vol. 8, no. 9 Special Issue 3, pp. 516-519.

20. Yugendhar, K., Sugumar, V. \& Kavitha, P. 2019, "A novel method of univac using fuzzy logic", International Journal of Innovative Technology and Exploring Engineering, vol. 8, no. 9 Special Issue 3, pp. 435-437.

21. Kaliyamurthie, K.P., Michael, G., Elankavi, R. \& Jijo, S.A. 2019, "Implementing aggregate-key for sharing data in cloud environment using cryptographic encryption", International Journal of Innovative Technology and Exploring Engineering, vol. 8, no. 9 Special Issue 3, pp. 957-959.

22. Jeffrin Rajan, M., Aravindasamy, R., Kavitha, P. \& Rama, A. 2019, "A novel method of object orientation variation in $\mathrm{C}++$ and java", International Journal of Innovative Technology and Exploring Engineering, vol. 8, no. 9 Special Issue 3, pp. 708-710.

23. Nayak, R., Dinesh, S. \& Thirunavukkarasu, S. 2019, "A novel method improvement of rapid miner for the data mining applications", International Journal of Innovative Technology and Exploring Engineering, vol. 8, no. 9 Special Issue 3, pp. 457-460.

24. Sivaraman, K., Krishnan, R.M.V., Sundarraj, B. \& Sri Gowthem, S. 2019, "Network failure detection and diagnosis by analyzing syslog and SNS data: Applying big data analysis to network operations", International Journal of Innovative Technology and Exploring Engineering, vol. 8, no. 9 Special Issue 3, pp. 883-887.

25. Vimala, D., Linda, I.M. \& Priya, K.S. 2019, "Decoupling online algorithms from erasure coding in DNS", International Journal of Innovative Technology and Exploring Engineering, vol. 8, no. 9 Special Issue 3, pp. 950-953.

26. Rama, A., Kumaravel, A. \& Nalini, C. 2019, "Preprocessing medical images for classification using deep learning techniques", International Journal of Innovative Technology and Exploring Engineering, vol. 8, no. 9 Special Issue 3, pp. 711-716.

27. Sangeetha, S., Srividhya, S.R., Anita Davamani, K. \& Amudha, S. 2019 , "A procedure for avoid overrun error in universal synchronous asynchronous receiver transmitter (usart) by utilizing dummy join and interrupt latency method", International Journal of Innovative Technology and Exploring Engineering, vol. 8, no. 9 Special Issue 3, pp. 657-660.

28. Aravindasamy, R., Jeyapriya, D., Sundarajan, B. \& Sangeetha, S. 2019, "Data duplication in cloud for optimal performance and security", International Journal of Innovative Technology and Exploring Engineering, vol. 8, no. 9 Special Issue 3, pp. 1156-1158.

29. Aravindasamy, R., Jeffrin Rajan, M., Sugumar, V. \& Kavitha, P. 2019. "A novel method on developing superblocks and the transistor using apodryal", International Journal of Innovative Technology and Exploring Engineering, vol. 8, no. 9 Special Issue 3, pp. 982-985.

30. Sasikumar, C.S. \& Kumaravel, A. 2019, "E-learning attributes selection through rough set theory and data mining", International Journal of Innovative Technology and Exploring Engineering, vol. 8, no. 10, pp. 3920-3924.

\section{AUTHORS PROFILE}

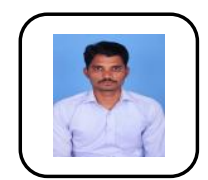

I.Govindharaj Assistant Professor, Department of Computer science and Engineering, Bharath Institute of Higher Education and Research, Chennai, India

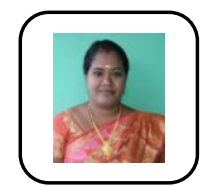

Vimala D Assistant Professor, Department of Computer science and Engineering, Bharath Institute of Higher Education and Research, Chennai, India

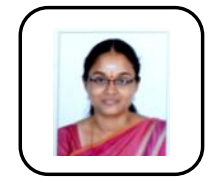

Shanmugapriya K Assistant Professor, Department of Computer science and Engineering, Bharath Institute of Higher Education and Research, Chennai, India 